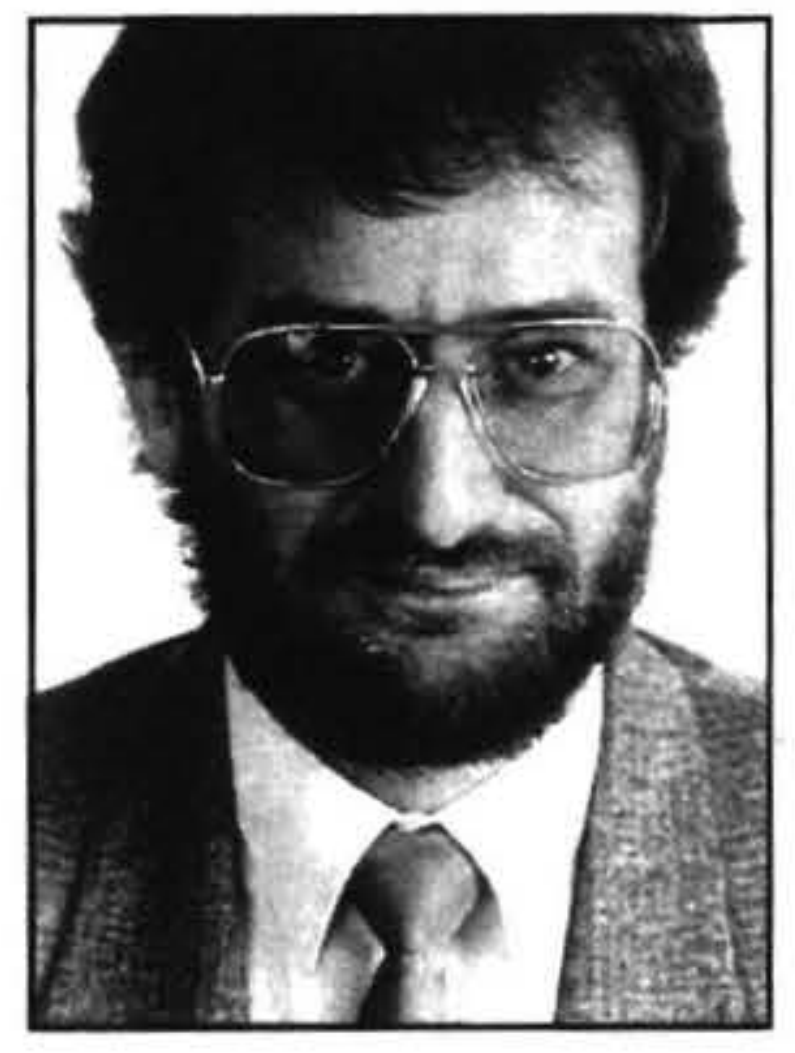

\title{
THE TRANSFORMATION OF NEW ZEALAND'S OCCUPATIONAL \\ SAFETY AND HEALTH (OSH) LEGISLATION AND ADMINISTRATION FROM 1981 TO 1992: A CASE OF REACTIONARY POLITICS
}

\author{
John Wren \\ Department of Sociology \\ Massey University
}

\begin{abstract}
From 1981 to 1992 New Zealand's occupational safety and health (OSH) legislation and administration has undergone a significant transformation. At the beginning of the period the situation can be described as a system of "Government Management", by 1990 a system of "Tripartite Management" had been partially introduced, in 1992 a new system of "Employer Hazard Management" had replaced existing arrangements. How did this transformation occur, why did it occur, and how does it compare with overseas examples? The transformation represents a case of reactionary politics. At the social level, change was a reaction to fears in the community about the dangers associated with the advent in New Zealand of large complex industrial plants, and the introduction of new chemicals. At the institutional level of organised actors, change was the result of reaction against perceived inadequacies in the existing legislative and administrative arrangements, and responses to positions adopted by competing actors. At the individual level change came about as organisations responded to the initiatives of certain individuals. By 1992, the colonial reliance upon overseas policy examples had been replaced with policy initiatives that reflected the level of knowledge amongst government officials, and the dominant forms of $\mathrm{OSH}$ management practiced by large New Zealand companies.
\end{abstract}

Analysis of interview and documentary material gathered for a doctoral thesis indicates that from 1981 to 1992 New Zealand's occupational safety and health (osh) legislation and administration has undergone a significant transformation. The first part of the paper identifies, characterises and assesses the significance of the changes that have occurred. In the course of conducting the analysis, the main events in the change process are identified. A quick explanatory account for the legislative and administrative outcomes, and length of time taken for change to occur, is then given. The paper finishes by highlighting similarities between the New Zealand osh policy experience as described here, with a number of similar analyses reported in the international literature.

During the period 1981 to 1992 New Zealand's occupational safety and health legislation and administration under went a significant transformation. At the beginning of the period of change, 1981, the situation can be described as a system of "Government Management", while by 1990 a system of "Tripartite Management" had been partially introduced, and in 1992 a new system of "Employer Hazard Management" replaced existing arrangements. A summary of these changes is presented in Figure 1 on the next page. The diagram serves to highlight the fact that anecdotal and other descriptions of the changes throughout the period as representing Robens style reform, de-regulation, or "self-regulation" (Hughes, 1993:1), are at best only partially accurate. To quote a representative of the New Zealand Business Roundtable, "the objective is not deregulation as such, but reform of regulation" (Brook, 29 June 1989:8). In addition, descriptions of the eventual outcome as representing a hazards management or risk management approach to osh, while accurate, do not adequately depict all the changes that have occurred, nor the continuities that remain. By discriminating more carefully between the different approaches in terms of the points of emphasis in each period, and in understanding the policy philosophy behind them as identified in the figure, a better description and understanding of the changes that have occurred can be arrived at.

In 1980 the Walker Report (1981:9) described New Zealand's legislation as serving the function of "occupational hygiene", in that it focussed upon the control of specific types of hazards by specific means in particular industry and occupational groups. The approach suffered though from gaps in workplace coverage, and from anomalies in jurisdictional application (Walker, 1981:1). To rectify this situation Walker recommended that New Zealand cautiously follow the British example as set out in the 1972 Robens Report (Walker, 1981: 4 \& 55-56). Subsequently, the Factory and Commercial Premises Act 1981 was passed. This Act amalgamated the 1946 Factories Act with the 1955 Shops and Offices Act, provided for the training of workers, set out the duties of employers and employees, signalled a move away from reliance upon detailed technical and prescriptive Regulations to less specific Codes of Practice (CoP), and provided for the possibility of health and safety committees and representatives. However the new legislation still left fourteen major Acts, seventeen minor Acts, and over fifty 
Figure 1. Summary description and characterisation of New Zealand's OSH legislative and administrative arrangements as at December 1981, 1990, 1992. $\odot$ John Wren 1996

\begin{tabular}{|c|c|c|}
\hline $\begin{array}{c}\text { Osh Situation at December } 1981 \\
\text { Government Management }\end{array}$ & $\begin{array}{c}\text { Osh Situation at December } 1990 \\
\text { Tripartite Management }\end{array}$ & $\begin{array}{c}\text { Osh Situation at December } 1992 \\
\text { Employer Management }\end{array}$ \\
\hline Administrative Arrangements & Administrative Arrangements & Administrative Amangements \\
\hline $\begin{array}{l}\text { Multiple Central Govemment } \\
\text { Authorities. } \\
\text { Some Local Govemment } \\
\text { Responsibility. }\end{array}$ & $\begin{array}{c}\text { Proposed: One Central } \\
\text { Administrative Authority } \\
\text { Comprised Of Three Institutions. } \\
\text { In process of establishment One } \\
\text { Central Govemment Authority } \\
\text { located in the OSH Service of } \\
\text { the DoL. }\end{array}$ & $\begin{array}{l}\text { One Central Govemment } \\
\text { Authority located in the OSH } \\
\text { Service of the DoL. }\end{array}$ \\
\hline Funded From General Taxation. & $\begin{array}{c}\text { Funded From Special Employer } \\
\text { Levy via ACC. }\end{array}$ & $\begin{array}{c}\text { Funded From Special Employer } \\
\text { Levy via ACC. }\end{array}$ \\
\hline Legislative Arrangements & Legislative Arrangements & Legislative Arrangements \\
\hline $\begin{array}{c}\text { Policy Philosophy: } \\
\text { Govemment Responsibility } \\
\text { (Modelled on Occupational } \\
\text { Hygiene Approach, and Part } \\
\text { Robens Report). }\end{array}$ & $\begin{array}{c}\text { Policy Philosophy: } \\
\text { Tripartite Responsibility } \\
\text { (Modelled on ILO OSH } \\
\text { Conventions, } 1972 \text { Robens } \\
\text { Report, and the Australian State } \\
\text { of Victoria of the early to mid } \\
1980 \text { s). }\end{array}$ & $\begin{array}{c}\text { Policy Philosophy. } \\
\text { Employer Responsibility } \\
\text { (Hazards Management Approach } \\
\text { Modelled on Loss Control and } \\
\text { Risk Management Approaches). }\end{array}$ \\
\hline Multiple Acts And Regulations. & $\begin{array}{l}\text { One Act, Multiple Regulations } \\
\text { And Codes Of Practice. }\end{array}$ & $\begin{array}{c}\text { One Act, Regulations } \\
\text { Progressively Replaced By } \\
\text { Multiple Codes Of Practice And } \\
\text { Guidelines. }\end{array}$ \\
\hline $\begin{array}{c}\text { Reliance Upon Prescriptive } \\
\text { Technical Specification Standards. }\end{array}$ & $\begin{array}{l}\text { Mix Of Prescriptive Technical } \\
\text { Specification Standards And } \\
\text { Performance Standards. }\end{array}$ & $\begin{array}{l}\text { Reliance Upon Prescriptive } \\
\text { Performance Standards, With } \\
\text { Minimal Prescriptive Technical } \\
\text { Standards. }\end{array}$ \\
\hline $\begin{array}{l}\text { Minimal Recognition Of Workers' } \\
\text { Rights. }\end{array}$ & $\begin{array}{c}\text { Positive Statements Of Workers' } \\
\text { Rights. }\end{array}$ & $\begin{array}{l}\text { Minimal Recognition Of } \\
\text { Workers' Rights. }\end{array}$ \\
\hline Limited Coverage Of Work Sites. & Full Coverage Of Work Sites. & Full Coverage Of Work Sites. \\
\hline Implicit Public Safety. & $\begin{array}{l}\text { Explicit Incorporation Of Public } \\
\text { Safety. }\end{array}$ & $\begin{array}{l}\text { Explicit Incorporation Of Public } \\
\text { Safety. }\end{array}$ \\
\hline $\begin{array}{l}\text { Mixed Liability Regime For } \\
\text { Employers: Absolute And Strict } \\
\text { Depending On Legislation. }\end{array}$ & $\begin{array}{l}\text { Strict Liability Regime For } \\
\text { Employers. }\end{array}$ & $\begin{array}{c}\text { Strict Liability Regime For } \\
\text { Employers. }\end{array}$ \\
\hline $\begin{array}{c}\text { Discriminatory Working } \\
\text { Provisions Against Women And } \\
\text { Young People. }\end{array}$ & $\begin{array}{c}\text { No Discriminatory Working } \\
\text { Provisions Against Women And } \\
\text { Young People. }\end{array}$ & $\begin{array}{l}\text { No Discriminatory Working } \\
\text { Provisions Against Women And } \\
\text { Young People. }\end{array}$ \\
\hline $\begin{array}{l}\text { Means to End: Effective } \\
\text { Government Action }\end{array}$ & $\begin{array}{l}\text { Means to End: Effective } \\
\text { Employee Action }\end{array}$ & $\begin{array}{l}\text { Means to End: Effective } \\
\text { Employer Action }\end{array}$ \\
\hline
\end{tabular}


Regulations pertaining to osh in force (ACOSH Report, 1988:3). One consequence of this multiplicity of regulation was that employers liability for health and safety varied from "absolute" to "strict". The Act also discriminated against women and young people in terms of hours of work and the types of work that they could do, and lacked any positive statement of workers' rights.

Administratively, responsibility for enforcing the legislation prior to 1981 and after the 1981 Act, was divided up amongst five government agencies, with Local territorial authorities having some responsibility. The government agencies concerned where:

1. the Department of Labour (DoL) which had primary responsibility for industrial safety;

2. the Department of Health (DoH) which had responsibility for occupational health;

3. the Ministry of Transport (MoT) which had responsibility for boilers, lifts and cranes, port side safety, and the safety of seaman;

4. the Ministry of Energy (MoE) which had responsibility for safety in mines and petroleum related activities; and

5. the Accident Compensation Corporation (ACC) which promoted health and safety at work through education and training, and provided in the middle 1980s an health and safety audit service.

Finally, funding of government activity in the osh area came from general taxation.

In sum the arrangement of osh policy at December 1981 relied heavily upon government action, that is, government management. It was an arrangement that the Deputy Prime Minister Geoffrey Palmer in 1984 called the "Balkanisation of control" (Speech G. Palmer, 10 July 1986:3, in DoL file, 19/5/51-3 Part 4). The system was limited in its coverage, rigid in its modus operandi, and paternalistic in its provisions against the employment of women and young people, and in its prescriptive technical specifications for the control of hazards.

By the mid-1980s some change had occurred. In May 1985 an officials only oversight committee, known as the Coordinating Committee on OSH, which had met with little success, was replaced by a tripartite 'advisory council' known as the Advisory Council on Occupational Safety and Health (ACOSH) (Cabinet Policy Committee Minute P(85) M 19 Pt4, 21 May 1985; in DoL files). The legislative discriminatory provisions against women and youth had been removed in 1982, extended paid Trade Union education was provided through the Trade Union Education Authority that had been established in 1986. In March 1987 a voluntary CoP for Health and Safety Committees and Representatives had been introduced on a trial basis. From 1986 onwards, funding of government osh related activity rapidly began to shift towards introduction of the 'user pays' principle. In the case of the DoL, funding for the Department's osh operations shifted in 1987 to a 'full cost recovery basis' through a special levy on employers that was collected via the ACC system (DoL paper "Funding of OSH and the ACC Levy" for Officials Working Party 16 September 1988:1, in DoL files).

More change was mooted in 1990 when new legislation was introduced into Parliament - the Occupational Safety and Health Bill (OSHB). The legislation was intended to replace all the previous legislation, proposed the extension of protection to all workers including the general public affected by any work activity, positively provided for workers' rights, intended the establishment of a bipartite Commission to advise Government on osh policy, placed more responsibility for osh action upon employers and employees including establishing a regime of 'strict' liability for employers, and undertook to replace prescriptive technical Regulations with less specific $\mathrm{CoP}$. The legislation was never passed. Administratively, by 1990 , responsibility for the enforcement of osh legislation had largely been delegated to the OSH Service of the DoL. Had the 1990 legislative proposals been introduced, New Zealand would have seen a tripartite management system for osh introduced. Paternal state intervention was going to be replaced by a system of joint government, union, and employer oversight and responsibility, that placed greater emphasis on employer and employee self-help.

In 1991 the OSHB was withdrawn from Parliament and a new Bill introduced. The passage of the Health and Safety in Employment Act (HSEA) in 1992 saw the introduction of the final changes transforming New Zealand's osh policy. The HSEA placed responsibility for osh solely upon employers, extended coverage to all workers including the general public, removed any reference to extended workers' rights and a bipartite advisory Commission, placed emphasis upon prescriptive performance standards rather than specific technical requirements, and confirmed that funding for government activities in osh should come from a special ACC levy on employers. Administratively, the $\mathrm{OSH}$ Service had completed the transfer of the various government agencies osh related resources to its control, and had contracted for the delivery to it of specific specialist services. Tripartism had been rejected in favour of minimalist government involvement and a system emphasising the rights and responsibilities of employers to manage their affairs. With the passage of the 1992 Act, the focus had shifted from the situation in 1981 of Government telling employers what hazards to prevent and how they were to be controlled, to setting out a specification of a desired level of management performance underpinned by the application of a regime of 'strict liability' in the event of an injury or illness occurring. Employer management responsibility was the new approach.

The question remains, why are these changes deemed "significant"? To answer this question two criteria derived from the theoretical work of Alain Touraine will be used. The first criteria asks, what is the degree to which the social relations of control have been significantly modified. The second criteria involves attempting to establish whether there has been any real change in the way that osh policy is thought about and administered by the bureaucrats concerned, and the other participating actors. 
Regarding the first criteria it is argued that the OSH Bill, if it had been passed, it would have brought about a significant change in the balance of control over health and safety at work from government and employers, too workers. The 1990 OSH Bill promised to give to workers and their representatives, far more formal power than they had ever had to protect their health. In addition to promising a rebalancing of power between workers and employers, the OSH Bill held the promise, through the establishment of an "Advisory Commission", of a shift in power over the control of government osh activity from politicians and officials, to greater oversight and participation by union and employer organisations. It was a shift that was particularly sought by union representatives, in order "to get some legitimacy [for a] union role in the workplace and [at the] national level [of] policy making about health and safety" (Interview 4:38489). It was an endeavour half heartedly supported by employer representatives because, at the time, it was politically expedient to do so. As one employer representative interviewed said: "Generally speaking with reservations, Employers Federation was committed to tripartism under the Labour government..... and if there [was] going to be a Health and Safety Commission 'by God' we were going to be on it" (Interview 7: 469-474). The rejection of the OSH Bill in favour of the HSEA by the 1990 National Government, effectively ended union attempts to shift the balance of control.

However in the context of a longer time frame and a wider perspective, the question has to be asked does the HSEA represent any significant shift from the beginning of the period as represented by the F\&CP Act 1981. This is a more difficult question to answer. On one hand it could be argued that the HSEA does represent a shift towards greater employer control, because employers have clearly been made explicitly responsible, and are now expected to actively identify and prevent workplace hazards without constant government oversight. Whereas the F\&CP Act while placing the responsibility for health and safety upon employers, in practice, the Act effectively depended upon government agencies to identify hazards and stipulate means of prevention. On the other hand there has been no significant shift between 1981 and 1992 since in both the F\&CP Act and the HSEA, workers' rights receive only a passing acknowledgment. Yet again, if a wider focus were to be taken that compared the industrial framework that existed in 1981 with that which exists now, it could be argued that in this context a significant change has occurred. At the beginning of the period a strong union support system existed, that no longer exists to the same degree today, thus there is less protection for workers now than there was then. Countering this point though, it could be argued that, while unions were certainly more powerful and prevalent in 1981 than they are now, unions are more knowledgeable and pro-active about health and safety than ever before.

In terms of the second criteria, the evidence is much clearer that a significant change has taken place. The documents show that the policy situation in 1981 in government agencies was essentially ad-hoc in nature, fragmented, largely based upon United Kingdom developments, and had no explicit philosophical foundations (DoL paper 'One Act One Authority' 4 February 1988: 7-8, in DoL file 19/9/3-1 Vol 2; and DoL paper "Legislation and Administration of Occupational Health and Safety" for $6^{\text {th }}$ ACOSH meeting 30 September 1986: section 1.2.2 \& 1.2.3; in DoL File 19/ 9/3-1 Vol 2). The F\&CP Act involved no major rethinking of how to manage osh, or fundamental change in the management of osh. Unions and employers had no formal policy statements on health and safety at work. However signs of significant change occurring, began to appear in 1983 with the advent of the first ever combined unions investigation into the role of workers in the management of osh (FoL/CSU Report, 1985). The investigation was completed in 1985. In 1983 the New Zealand Employers Federation published their first ever policy statement on health and safety for employers (The Employer:1983:4-5). In 1985 ACOSH was formed which was significant as it formally and publicly opened up discussion about osh policy beyond the confines of government agencies. In September 1988 the OSH Service of the DoL established its own policy unit, which lead in October 1988 to the development of a coherent set of 'preferred' policies.

The major change that has occurred, signalled by the $\mathrm{OSH}$ Bill and confirmed by the content of the HSEA, has been the development of osh policy in New Zealand that is not reliant upon overseas legislative examples, and is reflective of New Zealand's dominant form of knowledge in the late 1980s about osh prevention within government and big business (Wren, 1995). With the appearance of the 1990 OSH Bill came the first legislative proposals that had a predefined philosophical base. As one union interviewee said: "The OSH Bill really was the union agenda, that was our Bill, that was what we wanted...that we picked up from Victoria and South Australia" (Interview 1:286-287; 291). It was an approach buttressed by the Labour Government's initial support for possible ratification of $\amalg O$ Convention 151 on osh policy (Cabinet Policy Committee minute P (85) M19 Pt 4. May 1985, in DoL files).

The National Government though, preferred to adopt a philosophy of intervention advocated by big business in the form of representatives from members of the "Top Tier" group of industry (OSH Service Memo of meeting 5 July 1989, in DoL file HSEB \& A Vol 2). The representatives of these groups of employers suggested that government withdraw from any detailed intervention in their affairs. If government was to intervene, then it should use an approach that would promote the adoption by employers of "risk management systems" (OSH Service Memo of meeting 5 July 1989, in DoL file HSEB \& A Vol 2). Subsequently, officials of the OSH Service of the DoL chose to use the managerial philosophy found in the International Safety Rating System - of hazard identification, loss control, and audits - to construct and implement the new legislation (Interview 13: 1250-60 \& Interview 12:39-87; DoL Report to the Labour Select Committee 1992:116). It is the conscious adoption by big business and senior government officials of this particular form of intervention in osh that signifies a significant event. It is significant because it represents a clear break from dependence upon overseas 
legislative models, and it reflects a policy solution clearly representative of the dominant philosophy of health and safety management found in large New Zealand businesses, and amongst senior government officials (Wren, 1995; Interview 13: 1250-60). It is also significant because it is consciously designed to be compatible with the industrial relations framework established in the Employment Contracts Act 1991, and the accident compensation changes of 1992. It is also compatible with the 'new right' economic philosophy implemented in New Zealand since 1984.

The question now is, how are these change outcomes to be explained. It is clear from the interviews and the documentary material, that the change process primarily originated in the mid-1970s within organisations representing workers and employers. Unions desired change because the existing arrangements were perceived as ineffective - particularly from 1974 onwards with the death of 5 workers in a chemical explosion in Petone in that year. There was also an awareness amongst union leaders and researchers of changes in overseas occupational safety and health legislation (Interview 3: 1-114, 542-44; Letter from Kjellström to Fol 10 March 1980, National Library, FoL File 5/9 F\&CP Bill $1977-\mathrm{Dec} 1980$ ). The awareness led to the idea in the early 1980 s in the union movement that the time was appropriate for New Zealand to update its legislative and administrative arrangements (Interview 3: 1-114, 542-44). At the same time employers desired change because they thought the multiplicity of administrative systems and regulatory provisions were technically and economically outmoded, interfering, and ineffective (Interview 6:28-58). Another pressure point for change was an awareness amongst big business and DoL officials of increasing concern within the general public about the effects of new chemicals and technology upon the health of individuals, communities, and the environment (Interview 6:292-93, 298-309; Interview 11:86-88; DoL paper 30 September 1986: section 1.2.2; in DoL File 19/9/3-1 Vol 2). Another source for change were demands from the mid-1980s onwards from Government Ministers for greater administrative efficiency and accountability from government agencies (DoL paper, 30 September 1986: section 1.2.2 \& 1.3.1; in DoL File 19/9/3-1 Vol 2).

These demands for change in osh policy can be characterised and explained as a crisis of integration and a crisis of rationality (Touraine, 1977:87-88). A crisis of integration is one where a social problem exists that involves a contradiction in the organisation of work in capitalist economies. A crisis of rationality occurs when existing regulatory modes are perceived to be no longer working nor appropriate for new technologies and production methods. The demands for change from unions on the basis that the existing osh policy was failing workers and that workers needed more power to protect themselves, would indicate a crisis of integration. In contrast, demands for change from employers representatives on the basis that the existing regulations were outmoded and inefficient indicate a crisis of rationality.

It is also clear that the 'general direction' of the reforms were determined by the national elections changing the patterns of power between the representatives of the two main opposing social classes (workers and employers) and their agents in the political-institutional sphere of action (the Labour Party and the National Party respectively). The 'detailed content' of the reforms though, reflects the particular rational reconciliation by policy advisers within the OSH Service of the general direction given by the political decision makers, with the resources available, and their levels of knowledge. This does not explain though why a reformist and ostensibly pro-worker Labour Government could not pass new osh legislation after six years in power, while a pro-employer National Government did within two years of coming to power. However a number of reasons can be found, to explain this phenomena.

The first reason is that osh reform in the first term of the Labour Government was very much a secondary priority for the Minister of Labour, whose first priority was the reform of industrial relations and public sector management (Rodger, S. Speech 4 February 1988:3, in CTU file Health \& Safety Reps Vol 1). With reference to the second term in office, the lack of progress may in a small part be explained by the turmoil within the leadership of the Labour Party in 1989, one result of which was the loss of Stan Rodger as the Minister of Labour early in August 1989. However this 'loss' brought another very able politician to the portfolio Dr Michael Cullen, who saw the legislative reforms introduced into Parliament.

Another reason for the lack of earlier progress can be found in the delay caused by the desire for "consensus" by Labour politicians over the introduction of health and safety committees and delegates (Fourth ACOSH Minutes 27 May 1986: 2, in DoL File 19/9/3-1 Vol 1; Fifth ACOSH Minutes 22 July 1986:3-5, in DoL File 19/9/3-1 Vol 1; Speech, E. Isbey 25 September:31-32, in DoL files; Speech, Rodger, S. 4 February 1988:17-18, in CTU file Health \& Safety Reps Vol 1). The delay caused by the deadlock over this issue was highlighted by officials who wrote to the Chair of ACOSH Mr Isbey late in September 1986:

\footnotetext{
"The Department considers that it is essential that ACOSH reach a decision on this topic at the next meeting, as there is a possibility that ACOSH will lose credibility, both within its member organisations and outside, if it is not able to conclude this matter soon. There are also other important topics which cannot be properly considered while this subject dominates the agenda" (DoL Memo to Mr Isbey, 23 September 1986, in DoL files).
}

A further factor explaining the delay in osh reform can be found in the fact that neither political party had a coherent well thought-out policy on osh, this is particularly true of the National Government. For example, Labour's 1984 policy consisted of one sentence in its industrial relations policy statement that said Labour will:

"legislate to provide for occupational health services; improve the quality of the work environment; enforce requirements for health and safety standards in the workplace; provide for health and safety delegates and 
committees at the workplace" (DoL background paper for Cabinet minute P (85) 61, 14 May 1985:2, in DoL files).

As for the National Government, the Minister of Labour Mr Birch has acknowledged that "the Government had no feel for the issues in the osh area, unlike for employment contracts where the policy was clear" (Record of meeting in Minister's office, 16 May 1989, in DoL file HSEB \& A Vol 2 ). The consequence of not having a well defined and thought out policy was that both Labour and National Government politicians had to learn about the topic in a climate of strong conflicting advice from government agencies, while under pressure for change from their client supporters.

To digress at this point to an osh policy issue; the examples given above while illustrating the lack of developed policy on osh amongst the two key political parties, they also clearly show that osh is considered an integral component of the 'industrial relations system' by both the political parties. Both the Labour and the National Government's changed the industrial relations legislation prior to considering osh reform. Not only is osh considered an industrial relations issue, it is now established in New Zealand thanks to Treasury and the DoL, that the issue is discussed in the context of the 'labour market'. This means that any future discussion about osh policy rather than being framed in terms of wages, holidays, and working conditions, is now framed in the wider context of economic efficiency, employment growth, immigration, and industry training. One important implication of this finding is that it belies any arguments from employers representatives that osh is not an industrial relations issue, especially where the issue of workers' rights and health and safety committees is being discussed. As one employer's representative interviewed put it:

"The employers' line was that this [was] not an industrial relations issue, we want industrial relations kept out of it, that was our absolutely solid line. But the reality is that when your talking about health and safety representatives and so on, you can't do it without having the labour relations framework set up" (Interview 7:317-20). "Once you've done that, once you have looked at what your industrial relations philosophy is, then the other things are going to flow out of that" (Interview 7:828-29).

Returning to reasons why the Labour Government failed to implement reform, there is clear evidence that suggests the Labour Government Minister of Labour Mr Stan Rodger was not that committed to the union proposals for health and safety committees and delegates, nor to the ACOSH proposals. Regarding implementation of compulsory health and safety committees and delegates, in a letter to the New Zealand Employers Federation Mr Rodger commented: "I agree that introducing a mandatory system of Health and Safety committees under the present legislation would probably have little benefit and could possibly affect industrial relations adversely" (Letter Minister of Labour to EF 26 July 1989:1, in DoL file 19/9/3-2). As for the ACOSH proposals, the preface to the $1988 \mathrm{ACOSH}$ Report clearly indicates that the Report's recommendations did not represent Government policy, and that the Government reserved the right to re-investigate the issue.

Another factor that can be identified as contributing to the delay was the constant re-litigation of the issues by all the parties, particularly by government officials. One example, of the re-litigation of issues by officials can be seen in the actions of Area Health Boards (AHBs). Even after the recommendations of the "majority" of the 1989 Officials Report and the 1990 Transition Team Report were accepted by Cabinet (CAB (89) M23-17 10 July 1989; CAB (89) M45/46 18 December 1989; POL (90) M1-1 24 January 1990) other officials from the Ministry of Transport, Ministry of Energy, and the AHB's in particular, resisted the proposed changes. As late as April 1991 the OSH Service had to request the intervention of the Minister of Labour $\mathrm{Mr}$ Bill Birch to "remove obstacles encountered in discussions with (Area Health) boards" who are attempting to "relitigate the issues" over the transfer of occupational health staff and related financial resources to the OSH Service (Letter from OSH Service to Minister of Labour, 30 April 1991:1\&3, in DoL file HSEB \& A Vol 1).

However, none of these reasons explain the phenomena of why a pro-employer party passed reforming osh legislation. The answer to this question is quite simply that, employers genuinely wanted reform albeit on their own terms. In addition the National Government did not have to do anything to reform the administration of osh, as this had already been largely completed by the Labour Government. Furthermore while the National Government did pass legislation, it is highly probable they would not of, if they hadn't been faced with the OSH Bill on the Parliamentary agenda, and if employers weren't so keen to see reform proceed themselves, particularly the removal of any threat to their managerial prerogatives posed by the OSH Bill (OSH Service Memo of meeting 5 July 1989 , in DoL file HSEB \& A Vol 2).

Turning to the international literature on osh policy making, analysis shows that there are three core policy issues commonly debated in all nations (Wren, 1996). The first issue involves deciding the extent to which the state should intervene in regulating occupational safety and health. The next debate concerns consideration of how the state should instrumentally intervene in regulating occupational safety and health. For example should the state intervene by the use of legal precepts such as "strict liability" or more general "liability rules". The third key debate revolves around the extent to which workers' rights should be recognised. All three issues appear in the New Zealand debates.

Throughout the change process in New Zealand the Treasury and employers representatives argued for a minimalist role for government in osh, while the unions and the DoL have consistently argued for a stronger role. After the DoL established the case for government intervention, debate between all the parties raged over how government should intervene. The unions supported mechanisms that would 
promote stronger standards and better enforcement. The employers supported a shift towards performance standards rather than strict technical specifications, and wanted more emphasis upon education about mechanisms to prevent workplace injuries and illnesses. The DoL supported measures such as the application of "strict liability" rules that would make enforcement easier. Treasury argued for a system that would allow parties to negotiate their own level of osh related risk in employment contracts, and which would be enforced through the freedom of individuals to take punitive tort actions in the courts. The issue of workers' rights was the major source of contention and difference between union and employer representatives, and their respective political allies throughout the period.

Turning to more specific comparisons in the literature, Ashford's (1976:535) conclusion that conflict is inherent in American occupational safety and health policy because of competing self-interests, lack of knowledge, differences in values, conflicts over governmental jurisdiction, and differences in disciplinary perspectives, and similar sentiments by Doern (1977:16) in relation to Canada, is consistent with the New Zealand experience from 1981 to 1992 . All the New Zealand participants in the process were competing to protect and enhance their positions. Positions that were based, in the case of employer and union representatives, upon differences about the perceived behaviour of the other in the workplace. Mendeloff's (1979:22) observation that the "debates over procedural and substantive issues often revealed underlying differences in perceptions of management behaviour and the workings of the labour market" is particularly pertinent at this point. In the case of New Zealand government officials, differences between the labour market perspective of the DoL, the health perspective of the $\mathrm{DoH}$ and later on the Area Health Boards, and the economic rationalism of Treasury all contributed to prolonging the process of reform, as politicians sought in vain for unanimity in advice from officials.

The comments by Boehringer and Pearse (1986) that Australian Commonwealth osh policy since the 1920 s has seen the development of a dichotomy and conflict for domination between the domains of medicine and industrial relations, between health as a Health Department responsibility and safety a Labour Department responsibility, is equally the case in New Zealand up until the reforms of the late 1980s. In the end the conflict in New Zealand was resolved by subsuming the health perspective under the domination of the 'Labour Market' perspective of the DoL and Treasury, and with a deliberate attempt to circumvent the dichotomy between "health" and "safety" by concentrating upon "hazards" as opposed to individual "safety" and "health" matters.

In the context of the ACOSH Report (1988) recommendations for new tripartite administrative structures, Doern's (1977:27) comment that in Canada the key issue is really the level of "political will and resources available to the organisation rather than...any superficial or stylish preferences for the 'board' or the 'departmental' model", would seem to be equally relevant in New Zealand. The comparison is especially pertinent given that the changes that have taken place in New Zealand have not seen any additional resources expended by Government on osh. Another observation made by Doern that is applicable to New Zealand up to the late 1980s at least, is his noting of the problem of interdepartmental and intra-departmental coordination and conflict, as the result of "empire building" and more simply the historical fact that most departments had been given many functions by past governments (Doern, 1977:27).

A number of observations by another Canadian, Robert Sass (1986; 1989: 1993), also have a resounding echo in the New Zealand experience. Sass (1989:157) has pointed out that throughout the 1970s occupational safety and health law in Canada underwent a broadening of concerns to include the issue of workers' rights. The same could be said for New Zealand albeit ten years later, and with different results. Sass (1989:158) identifies the source for this "broadening of concerns" as Sweden and Norway; the same Nordic countries that the Walker Report referred to in 1981, and which inspired the first union moves to incorporate workers' rights into New Zealand legislation. Sass' (1989:165) comment that Canadian "management generally favoured the 'right to know', felt more reserved about 'effective' health and safety committees or the workers' right to participate, and definitely opposed the workers' 'right to refuse' dangerous work", also beautifully describes the attitude expressed by New Zealand employers representatives on the same issues. Another observation by Sass (1989:163-164) that has a resonance in New Zealand, is his view that osh policy in Canada, particularly in relation to workers' rights, is discussed in the context of "management prerogatives" and "liberal utilitarian concept of justice and not upon democratic criteria". The resonance in this observation of Sass', is heard most clearly in the policy position espoused by Treasury (Treasury paper T90/1875:1, 28 May 1990; Treasury paper T91/34336 August 1991; Treasury letter to Minister of Finance, 15 August 1991) and the New Zealand Business Roundtable (1988)

Another point that appears in the literature, which can be seen to have a strong echo in New Zealand, is the absolute fiction of the "'traditional hegemonic ideology" associated with osh that osh is divisible from industrial relations (Carson 1970, 1974, 1979, 1980, 1982, 1985, 1989; \& Henenberg, 1988; \& Johnstone, 1990; Quinlan, 1993:140-150; Creighton \& Gunningham, 1985:3-5; Beaumont, 1983). The separation of occupational safety and health from industrial relations as a policy issue is a fiction particularly encouraged by the employers. The purpose of the distinction can only be seen as an ideological one that serves employers purposes, as it is a useful negotiating tactic to limit any gains by workers in one arena of industrial relations from being transferred to another. In New Zealand the fiction has no basis in reality, as indicated by the comments made by employers representatives interviewed, the fact that both political parties in New Zealand explicitly situate their osh policy within their industrial relations policy, and that osh policy is now discussed in the context of the 'labour market'.

Another similarity between the literature and the period of change in New Zealand under the Labour Government, is the 
aptness of Gräbe's (1991) analysis regarding tripartite osh policy processes in Great Britain. Gräbe (1991:59) comments that while tripartite arrangements are a way of enhancing the likelihood that new regulations will be accepted, they are "slow", as consensus is always sought in decisions made. Furthermore where a consensus outcome fails to occur, stalemate results and the parties move their debate to another arena. Delay in the process is exacerbated because "much happens behind the scenes, including intervention by senior management people, and informal trade-offs are part of the procedure [and] the compromise reached at the end strongly reflects the power that the participant groups represent outside the scope of a particular committee" (Gräbe, 1991:60). Gräbe's analysis describes very closely the reform process under the Labour Government, and in particular the course of the debates in ACOSH over the voluntary CoP for Health and Safety Committees and Delegates.

The final study in the literature that has a clear reflection in the New Zealand policy debates between Treasury and DoL officials in 1991, is Gunningham's (1984) analysis of safety law in Australia. Particularly interesting here is, is his discussion of the methods of prosecution that can be adopted, and the form of establishing guilt for osh offences (Gunningham, 1984:77-87, 275-297). For Gunningham (1984), establishing guilt means proving beyond reasonable doubt what the defendant's intention was (eg 'state of mind' -mens rea) when the alleged offence occurred. In some cases, it is sufficient to only show that 'negligence' has occurred. The issue of "mens rea" is critical, unless it has been replaced by a concept of "absolute" or "strict" liability, as usually happens with occupational safety and health law. In which case it is sufficient to only prove that the event occurred regardless of the defendant's intention (Gunningham, 1984:82-83). The justification for this approach is public interest in "efficient law enforcement" (Gunningham, 1984:82, footnote 24). ${ }^{1}$

An alternative to "strict liability" is the preference for "liability rules" orientated towards establishing the case for negligence that is put forward by economists from the Chicago school of economic thought (Gunningham, 1984:275-87). ${ }^{2}$ In the context of occupational safety and health, negligence rules would assign rights and responsibilities to specific parties based upon assessment of duty of care and the costs and benefits associated with compliance. Liable negligence would be established where a party failed to take cost justifiable actions that would have prevented the unwanted event from happening. The justification for this legal preference is that freedom of choice is enhanced, and the need for costly state enforcement would be reduced as the "liability rules" replicate market forces that would apportion costs efficiently and thus help promote injury/illness prevention (Gunningham, 1984:287). This discussion by Gunningham of alternative forms of government intervention reads as a 'script' for the arguments put by Treasury and the DoL to Government in August 1991. Treasury arguing for the application of negligence and liability rules (Treasury paper T90/1875:1, 28 May 1990; Treasury paper T91/ 34336 August 1991; Treasury letter to Minister of Finance, 15 August 1991), the DoL arguing for strict liability (DoL paper, 1 October 1988:17-18; OSH Service report to Minister of Labour, 22 August 1991:1-4). The confluence here of Gunningham's discussion with the New Zealand debates, highlights the common British legal heritage that both countries share and the influence that has upon how osh legislation is framed.

\section{Summary}

In summary significant changes have occurred in New Zealand's osh policy during the period 1981 to 1992 . At the beginning of the period the situation can be described as a system of "Government Management", by 1990 a system of "Tripartite Management" had been partially introduced, in 1992 a new system of "Employer Hazard Management" had replaced existing arrangements. Furthermore, by 1992, the colonial reliance upon overseas policy examples had been replaced with policy initiatives that reflected the level of knowledge amongst government officials, and the dominant forms of OSH management practiced by large New Zealand companies. The origins of these changes can be traced to a crisis of integration and rationality. A comparison of the osh policy literature with the New Zealand experience shows that there is a high degree of convergence between New Zealand and the policy issues debated overseas, and the policy positions taken by participants - irrespective of cultural differences and institutional arrangements. Various comments by observers of the osh policy process and debates in Canada, Great Britain, and Australia, can be seen to have direct relevance to New Zealand. The comparison highlights the fact that at the core of osh policy in New Zealand and world wide, is a conflict, inherent within the capitalist system of production, over the forms of control of the social relations of health and safety in the workplace. It is a conflict whose outcome is determined by who holds the balance of power in the political system, and the dominant level of knowledge amongst government officials.

\section{Future research}

The opportunities for research into the subject of occupational safety and health in New Zealand are endless. Three areas of future research can be quickly identified. Evaluative research into the efficacy of New Zealand's current approach to the regulation of occupational safety and health is an imperative. However such research is fraught with many difficulties. Difficulties such as the lack of reliable New Zealand statistical data, and problems associated with any international comparison. Another priority for investigation is how to balance the tension between the desire for the promulgation of non-prescriptive standards while providing sufficiently detailed information that is potentially technically prescriptive, confusing and quickly out of date. The third area of research is a real need for analysis that is critically aware and theoretically informed about the relationships between occupational safety and health policy issues and the management of occupational safety and health in the workplace. Any New Zealand literature search quickly reveals that there is a dearth of such literature. Provision of such analyses would improve the debates surrounding the regulation of occupational safety and health 
in New Zealand, and hopefully lead to the development of innovative solutions appropriate to New Zealand.

\section{Notes}

1. According to Gunningham (1984:83) there are two defences to "strict" liability: (1) "reasonable mistake of fact", and (2) "circumstances beyond the defendants control". The applicability of these defences depends upon the wording of the statutes concerned and the criminal code that applies in the particular jurisdiction.

2. For example: Steigler (1971); Diehl \& Ayoub (1980) in Peterson \& Goodale (ed); Walter (1973, 1974); Rinefort (1977); Smith (1980) in Peterson \& Goodale (ed); Coase (1960); Viscusi $(1979 ; 1983,1996)$.

\section{References}

Advisory Committee on Occupational Safety and Health. 1988 Public Discussion Paper: Occupational Safety and Health Reform Wellington: Government Print

ACOSH Fourth Minutes 27 May 1986, in DoL File 19/9/ 3-1 Vol 1.

ACOSH Fifth Minutes 22 July 1986, in DoL File 19/9/3-1 Vol 1.

Ashford, N. A. (1976). Crisis in the workplace: Occupational disease and injury: a report to the Ford Foundation Cambridge, Mass: MIT Press.

Beaumont, P.B. 1983 Safety at work and the Unions London: Croom Helm.

Boehringer, G.H. \& Pearse, W. 1986 Commentary: Commonwealth occupational health and safety policy and practice - a critique. Community Health Studies, 10(1), 80-94.

Brook, P.J. 29 June 1989 Safety and Health within a deregulated society: The case for a unified approach. Speech to the New Zealand Institute of Safety Management.

Cabinet Policy Committee minute P(85) M 19 Pt4,21 May 1985; in DoL files.

Cabinet Policy Committee minute P (85) M19 Pt 4. May 1985, in DoL files.

Cabinet minute CAB (89) M23-17 10 July 1989.

Cabinet minute CAB (89) M45/46 18 December 1989.

Cabinet Policy Committee minute POL (90) M1-1 24 January 1990.

Carson, W. G. 1970 White collar crime and the enforce- ment of factory legislation. British Journal of Criminology, 10, 383-398.

Carson, W. G. 1974 Symbolic and instrumental dimensions of early British factory legislation. London: Heinemann.

Carson, W. G. 1979 The conventionalisation of early factory crime. International Journal of Sociology of Law, 7, 37-60.

Carson, W. G. 1980 The institutionalisation of ambiquity: early British factory Acts. Beverly Hills: Sage.

Carson, W. G. 1982 The other price of Britain's oil: safety and control in the North Sea. New Brunswick: Rutgers University Press.

Carson, W. G. 1985 Hostages to history: Some aspects of the occupational health and safety debate in historical perspective. Sydney: Croom Helm.

Carson, W. G., \& Henenberg, C. 1988 The political economy of legislative change: Making sense of Victoria's new occupational health and safety legislation. Law in Context, 6(2), 1-19.

Carson, W. G. 1989 Occupational health and safety: A political economy perspective. Labour and Industry, 2(2), 301-316.

Carson, K., \& Johnstone, R. 1990 The dupes of hazard: Occupational health and safety and the Victorian sanctions debate. Australia New Zealand Journal of Sociology, 26(1), 126-141.

Coase, R. H. 1960 The problem of social cost. Journal of Law and Economics, 3(1):1-44.

Creighton, W. B., \& Gunningham, N. (eds) 1985. The industrial relations of occupational health and safety. Sydney: Croom Helm.

Diehl, A. E., \& Ayob, M. A. 1980 Occupational Safety and Health Standards: Cost, effectiveness and allocation of resources. In Peterson \& Goodale (ed) Readings in Industrial Accident Prevention. McGraw Hill: 49-64.

Doern, G. B. 1977 The political economy of regulating occupational health: The Ham and Beaudry Reports. Canadian Public Administration , 20(1), 135 .

DoL background paper for Cabinet minute P (85) 61, 14 May 1985:2, in DoL files.

DoL Memo to Mr Isbey, 23 September 1986, in DoL files.

DoL paper Legislation and administration of Occupational Health and Safety for $6^{\text {th }}$ ACOSH meeting 30 
September 1986, in DoL File 19/9/3-1 Vol 2.

DoL paper One Act/One Authority 4 February 1988: 7-8, in DoL file 19/9/3-1 Vol 2.

DoL paper Funding of OSH and the ACC Levy for Officials Working Party 16 September 1988, in DoL files.

DoL paper, 1 October 1988

DoL 1989 May Officials Working Party Report

DoL 1990 Transition Team Report

Grabe, S. 1991 Regulatory agencies and interest groups in occupational health and safety in Great Britain and West Germany: A perspective from West Germany. Law and Policy, 13(1), 55-72.

Gunningham, N. 1984 Safeguarding the Worker. Melbourne: Law Book.

Hodson, G. June 1983 Health and Safety Practice for Employers. The Employer:4-5.

Hughes, J. 1993 Enforcing safety standards: present developments and future. Employment Law Conference

Isbey, E. Speech 25 September 1986, in DoL files.

Interview 1. Wren, J. 1995. Doctoral Research Interview.

Interview 3 Wren, J. 1995. Doctoral Research Interview.

Interview 4. Wren, J. 1995. Doctoral Research Interview.

Interview 6. Wren, J. 1995. Doctoral Research Interview.

Interview 7. Wren, J. 1995. Doctoral Research Interview.

Interview 13. Wren, J. 1995. Doctoral Research Interview.

Letter from Kjellström to Fol 10 March 1980, National Library, FoL File 5/9 F\&CP Bill 1977-Dec 1980.

Letter Minister of Labour to EF 26 July 1989, in DoL file 19/ 9/3-2.

Letter from OSH Service to Minister of Labour, 30 April 1991, in DoL file HSEB \& A Vol 1.

Mendeloff, J. 1979 Regulating Safety: An economic and political analysis of Occupational Safety and Health Policy. Cambridge, Massachusetts: MIT Press.

New Zealand Business Roundtable 1988 Regulating for OSH: A submission to the Minister of Labour Wellington.
New Zealand Federation of Labour and Combined State Unions 1985 Occupational Health and Safety Project 1983-1985 Report Wellington:CTU

Oi, W. 1974 On the economics of industrial safety. Law and contemporary problems 38(4): 538-555.

OSH Service report to Minister of Labour, 22 August 1991.

OSH Service Memo of meeting 5 July 1989, in DoL file HSEB \& A Vol 2.

Palmer, G.Speech 10 July 1986, in DoL file, 19/5/51-3 Part 4.

Quinlan, M. 1993 Work and health: The origins, management and regulation of occupational illness. Australia: Macmillan Education Australia Pty Ltd.

Rinefort, F. C. 1980 A new look at occupational safety...a cost benefit analysis of selected Texas industries. In Peterson, O. and Goodale, J. Readings in Industrial Accident Prevention, McGraw Hill, New York: 36-48.

Rodger, S. Speech 4 February 1988, in CTU file Health \& Safety Reps Vol 1.

Robens Report 1972 Safety and Health at Work: Report of the Committee 1970-72 London: Her Majesty's Stationary Office.

Sass, R. 1986 Workplace health and safety: Report from Canada. International Journal of Health Services, 16(4): 565-582.

Sass, R. 1989 The implications of work organisation for occupational health policy: The case of Canada. International Journal of Health Services, 19(1): 157-173.

Sass, R. 1993 The Work Environment Board and the limits of social democracy in Canada. International Journal of Health Services, 23(2): 279-300.

Smith, R. S. 1980 The feasibility of an "injury tax" approach to occupational safety. In Law and contemporary problems 38(4):730-744

Steigler, G. 1970 The Optimum Enforcement of Laws Journal of Political Economy 78: 526-536.

Touraine, A. 1977 The self-production of society. Chicago:University of Chicago Press

Treasury paper T90/1875, 28 May 1990.

Treasury paper T91/3433, 6 August 1991.

Treasury letter to Minister of Finance, 15 August 1991. 
Viscusi, W. K. 1996 Fatal tradeoffs: public and private responsibilities for risk. New York: Oxford University Press.

Viscusi, W. K. 1979 The impact of occupational safety and health regulation. Bell Journal of Economics, 10, 117-140.

Viscusi, W. K. 1983 Risk by choice: regulating health and safety in the workplace. Cambridge: Massachusetts: Harvard University Press.

Walker, I. 1981 Occupational safety: an inquiry into the coordination of legislation on industrial safety, health and welfare. Wellington: State Services Commission

Wren, J. 1996 The Transfromation of New Zealand's OSH Legislation and Administration From 1981 to 1992. Chapter 2 Literature. Doctoral Thesis. Massey University.

Wren, J. 1995 A Survey of New Zealand occupational safety and health practitioner: dominant perspectives and the efficacy of government enforcement and promotion of occupational safety and health. Journal of Occupational Health and Safety Australia-New Zealand, 11(4):373-379.

\section{Author}

John Wren is a doctoral student in the Department of Sociology, Massey University, PO Box 11-222, Palmerston North.e-mail: jwren@voyager.co.nz 